\title{
FINE STRUCTURE OF STYRENE GRAFTED CELLULOSE
}

\author{
By Machiko Shimada, Yoshihiko Kawakami, Hirokazu Akabori \\ and Yoshio Nakamura \\ (Faculty of Technology, Gunma University, Kiryu, Gunma 376, Japan)
}

\begin{abstract}
Graft copolymerization of styrene onto $r$-ray irradiated cellulose was carried out with various trunk polymers; untreated cotton cellulose, mercerized cellulose, and carbamoylethylated and carboxyethylated celluloses. Then the fine structures of styrene grafted celluloses were studied by measuring moisture regain, water imbibition and degree of crystallinity under dry and wet conditions. Although hydrophilicity of untreated cellulose, carbamoylethylated and carboxyethylated cellulose in 3\% sodium hydroxide solution and mercerized cellulose was not lost by grafting reaction, highly hydrophilic nature was lost by styrene grafting onto carbamoylethylated and carboxyethylated cellulose in $20 \%$ sodium hydroxide. Consequently it was confirmed that polystyrene grafts were introduced to amorphous regions in the first stage of grafting reaction, then to semicrystalline regions and finally to crystalline regions with disarranging the crystal structure. Such phenomena are the same in all samples, but the extent of grafting beyond which disarrangement of crystalline regions occurs depends on the samples. In other words, the amounts of amorphous and semicrystalline regions in the samples determine the behavior of grafting.
\end{abstract}

\section{INTRODUCTION}

It is known that cellulose is carbamoylethylated and carboxyethylated by acrylamide in the presence of alkali. ${ }^{1,2)}$ The amount of the substituents can be controlled by reaction conditions. ${ }^{3)}$ We have already studied on the fine structure of carbamoylethylated and carboxyethylated cellulose and found that the regions where these substituents are introduced depend on the reaction conditions. ${ }^{4)}$ In $3 \%$ sodium hydroxide aqueous solution, the substitution reaction takes place only in amorphous regions and the crystal form does not change. But in $20 \%$ sodium hydroxide solution, the substitution reaction proceeds with mercerization reaction and the substituents are distributed not only in amorphous regions but also in sem. crystalline and crystalline regions. The resultant cellulose has rough crystal structure and the crystalline regions can be destroyed in part by immersing the sample in water. The results confirmed by $\mathrm{X}$-ray method were consistent with those obtained by the measurements of moisture regain and water imbibition.

On the other hand, many workers have reported on graft copolymerization of vinyl monomers onto irradiated cellulose. ${ }^{5-9)}$ But the fine structure of grafted cellulose has scarcely been studied. ${ }^{10)}$ We have also carried out grafting reaction of styrene onto $\gamma$-ray irradiated cellulose, but the fine structure of grafted cellulose has not been investigated. ${ }^{11)}$ Therefore, fine structures of styrene grafted celluloses are studied by measuring moisture regain, water imbibition and degree of crystallinity in this paper. The main purposes of this paper are to clarify next points; 1) whether grafted polystyrene destroys crystalline regions of the samples or not, and 2) whether the regions where grafted polystyrene is introduced are different from the samples or not. For the purposes, various trunk polymers with various hydrophilicities were used; untreated cotton cellulose, mercerized cellulose, and carbamoylethylated and carboxyethylated celluloses. 


\section{EXPERIMENTAL}

\section{Materials}

Scoured cotton cellulose fibers of the Acala variety supplied by Kanebo Co., Ltd. were purified by extracting with hot benzene-ethanol mixture (1:1 volume ratio) for $24 \mathrm{~h}$. Then the cotton fibers were washed with methanol and distilled water and air-dried (U).

Acrylamide was purified by recrystallization from benzene for several times. Styrene was purified by passing through a column filled with activated alumina. Other chemicals used were reagent grade and were used without further purification.

\section{Alkali Treatment}

The purified cotton cellulose fibers were treated in $20 \%$ sodium hydroxide aqueous solution for $5 \mathrm{~h}$ at $20^{\circ} \mathrm{C}$. Then the fibers were washed with distilled water, immersed in $0.1 \%$ acetic acid, washed with distilled water until acetic acid was thoroughly removed, and then air-dried. The procedure is mercerization reaction and the resultant fibers are called mercerized cellulose $(M)$.

Carbamoylethylation and Carboxyethylation

The purified cellulose fibers were treated with aqueous solution containing acrylamide as much as possible and $3 \%$ sodium hydroxide at $30^{\circ} \mathrm{C}$ for $24 \mathrm{~h}$ (LAAM24). And others were treated with $7 \%$ acrylamide and $20 \%$ sodium hydroxide at $20^{\circ} \mathrm{C}$ for $1 \mathrm{~h}$ (HAAM1) and $10 \mathrm{~h}$ (HAAM10). Then the samples were washed with distilled water, $0.1 \%$ acetic acid and distilled water and air-dried. Degree of carbamoylethylation and carboxyethylation per anhydroglucose unit of the samples was determined by micro Kjeldahl method and back titration technique, respectively.

\section{Determination of Accessibility}

Samples were hydrolyzed with $2.4 \mathrm{~N}$ hydrochloric acid at $100^{\circ} \mathrm{C}$. After hydrolysis, samples were washed with distilled water, dried and weighed. The weight loss was plotted against hydrolysis time. Accessibility was determined by extrapolating the straight part of the weight loss vs. time curve to time 0 .

\section{$r$-ray Irradiation}

Dried samples were irradiated with ${ }^{60} \mathrm{Co} r$-rays at an exposure rate of $1.0 \times 10^{6} \mathrm{R} / \mathrm{h}$ at room temperature in nitrogen atmosphere.

\section{ESR Measurement}

ESR spectra of $r$-ray irradiated samples were measured with a JES ME ESR spectrometer with $100 \mathrm{kHz}$ modulation. The microwave power was $0.4 \mathrm{~mW}$, and under these conditions no saturation effect was observed. Radical concentration was calculated by the double-integration method. Coal was used as a standard sample for the determination of radical concentration.

\section{Graft Copolymerization}

After $r$-ray irradiation, the samples were grafted with styrene at $30^{\circ} \mathrm{C}$ in reaction mixtures composed of $2 \%$ styrene, $64 \%$ methanol and $34 \%$ water. Then the samples were washed with methanol and water, and extracted with benzene to remove homopolymers.

Extent of grafting ( $G$-on) was calculated according to the next equation.

$$
\mathrm{G}-\text { on }(\%)=\frac{\text { Weight increase by graft copolymerization }}{\text { Weight of trunk polymer }}
$$

\section{Moisture Regain}

The samples before and after grafting reaction were conditioned for 7 days at $65 \%$ R.H. and $20^{\circ} \mathrm{C}$ and weighed. Weight increase by moisture was determined as moisture regain.

\section{Water Imbibition}

After the weighed samples were immersed in distilled water for $24 \mathrm{~h}$ at room temperature, they were centrifuged for $4 \mathrm{~min}$ and weighed. The same procedure was carried out for several times to plot the weight increase by water against times of centrifuging. Finally, weight increase at time 0 was obtained by extrapolation, and the value was shown as water imbibition.

Degree of Crystallinity ${ }^{4}$ )

$X$-ray diffraction traces from the samples under dry conditions were obtained by using Rigaku Denki D-9C X-ray generator operated at $35 \mathrm{kV}$ and $18 \mathrm{~mA}$ with $\mathrm{Cu} \mathrm{K} \alpha$ radiation. The bundle of the fibers was set so that the fiber axes mutually parallel were rotated in the plane vertical to the $\mathrm{X}$-ray beam $(80 \mathrm{rpm})$. The diffraction intensity was measured at $2 \theta=6-50^{\circ}(\theta$ is the diffraction angle). And the diffraction intensity was also taken in the same angular range at the various azimuthal angles. Troughs of the diffraction curve were then connected to determine the amount of 
amorphous regions. Then the corrections to the diffraction traces were made for air-scattering, incoherent scattering, sample absorption, poralization and Lorenz factors. The degree of crystallinity of the samples was determined by the integral method as follows;

$$
\text { Degree of Crystallinity }(\%)=\frac{I_{\mathrm{t}}-I_{\mathrm{a}}}{I_{\mathrm{t}}} \times 100
$$

where $I_{\mathrm{t}}$ and $I_{\mathrm{a}}$ are the integral scattering intensities corresponding to the amount of the total and amorphous parts, respectively.

For measurement under wet conditions, the bundled samples were immersed in distilled water for $24 \mathrm{~h}$ at room temperature and pressed out so that pick up was $50 \%$ and were set in a sample container with a poly (methylmethacrylate)(PMMA) film window. The other measuring conditions were the same with those under dry conditions. To correct the diffraction traces for wet samples, the X-ray diffraction trace from water in the sample container with the PMMA window was also obtained. Water contribution was also subtracted from the diffraction traces under wet conditions in addition to the same way as that for dry samples.

For grafted samples, corrections of polystyrene were also made. Others were the same as those for dry or wet samples.

\section{RESULTS AND DISCUSSION}

\section{Substitution Reaction and Accessibility}

Carbamoylethylation and carboxyethylation of cellulose by acrylamide in sodium hydroxide aqueous solutions are thought to proceed as follows. ${ }^{1-3)}$

$$
\begin{aligned}
& \text { Cell- }-\mathrm{OH}+\mathrm{CH}_{2}=\mathrm{CHCONH}_{2} \stackrel{\mathrm{NaOH}}{\longrightarrow} \\
& \text { Cell-O- } \mathrm{CH}_{2} \mathrm{CH}_{2} \mathrm{CONH}_{2} \\
& \text { Cell-O- }-\mathrm{CH}_{2} \mathrm{CH}_{2} \mathrm{CONH}_{2} \stackrel{\mathrm{NaOH}}{\longrightarrow} \\
& \text { Cell-O-O- } \mathrm{CH}_{2} \mathrm{CH}_{2} \mathrm{COOH}
\end{aligned}
$$

Degree of carbamoylethylation and carboxyethylation per anhydroglucose unit and accessibility of the samples are shown in Table 1 . Although the degree of substitution of LAAM24 was rather high as compared with HAAM1 and HAAM10, accessibility of LAAM24 was very low and almost the same as that of untreated cotton cellulose (U). Accessibility of mercerized cellulose (M) increased a little as compared with those of $\mathrm{U}$ and LAAM24. Accessibility increased remarkably as carbamoylethyl and carboxyethyl reactions were carried out in $20 \%$ sodium hydroxide aqueous solutions. The results are consistent with those reported in our previous paper. ${ }^{4)}$ This means that both carbamoylethyl and carboxyethyl groups are introduced only in amorphous regions of LAAM 24 by reaction of cellulose and acrylamide in $3 \%$ sodium hydroxide aqueous solution. On the other hand, as substitution reaction takes place with mercerization reaction, substituted groups are introduced not only in amorphous regions but also in semicrystalline and crystalline regions of the samples reacted with acrylamide in $20 \%$ sodium hydroxide solution. Therefore, cellulose lost its rigid crystal structure as carbamoylethylation and carboxyethylation proceeded in the presence of $20 \%$ sodium hydroxide solution. Onto these samples grafting reactions of styrene were carried

\begin{tabular}{|c|c|c|c|c|c|c|c|}
\hline \multirow[t]{2}{*}{ Sample } & \multicolumn{4}{|c|}{ Reaction conditions } & \multicolumn{2}{|c|}{ D.S. ${ }^{1)}$} & \multirow{2}{*}{$\begin{array}{c}\left.\mathrm{Ac}^{2}\right) \\
(\%)\end{array}$} \\
\hline & $\mathrm{NaOH}(\%)$ & $\mathrm{AM}(\%)$ & $\operatorname{Temp}\left({ }^{\circ} \mathrm{C}\right)$ & Time $(h)$ & $-\mathrm{CONH}_{2}$ & $-\mathrm{COOH}$ & \\
\hline $\mathrm{U}$ & - & - & - & - & - & - & 11.1 \\
\hline LAAM 24 & 3 & $\infty 3)$ & 30 & 24 & 0.158 & 0.088 & 10.2 \\
\hline M & 20 & - & 20 & 5 & - & - & 19.0 \\
\hline HAAM1 & 20 & 7 & 20 & 1 & 0.094 & 0.025 & 40.0 \\
\hline HAAM10 & 20 & 7 & 20 & 10 & 0.028 & 0.119 & 52.2 \\
\hline
\end{tabular}
out.

\section{Graft Copolymerization}

Graft copolymerization reactions were carried

Table 1. Degree of substitution and accessibility of samples

1) D.S. . Degree of substitution per glucose residue

2) Ac Accessibility

3) $\infty$ : Acrylamide was dissolved until the solubility limit 
out under reduced pressure at $30^{\circ} \mathrm{C}$. The relation between reaction time and extent of grafting is shown in Figure 1. The extent of grafting increased as reaction time in all samples. HAAM10 showed lower extents of grafting than the other samples.

The amounts of radicals produced by $r$-ray irradiation at room temperature are almost same among the samples M, HAAM1 and HAAM10 as shown in Table 2. But they decreased by immersing the irradiated samples into water. The amounts of radicals decreased in water are different among the samples. The decreased radicals have possibilities to become grafting sites and to decay in water. In other words, the initiation for grafting reaction and the decay by water are competition reactions of the radicals.

Lower grafting percent of HAAM 10 may be due to its rough structure as compared with other samples. Decay of radicals is higher in amounts than the initiation reaction especially in the case of HAAM 10 .

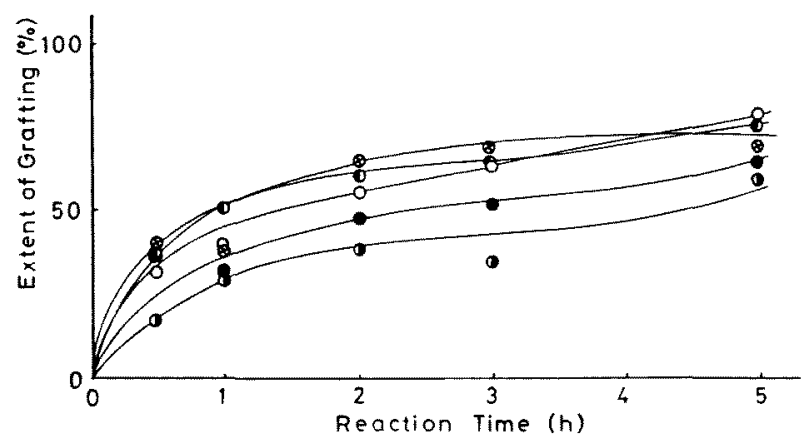

Fig. 1. Relation between reaction time and extent of grafting. $C$ : Untreated cotton cellulose (U).

$\&$ : Carbamoylethylated and carboxyethylated cellulose in $3 \%$ hydroxide for $24 \mathrm{~h}$ (LAAM24).

- Mercerized cellulose (M).

C : Carbamoylethylated and carboxyethylated cellulose in $20 \%$ sodium hydroxide for $1 \mathrm{~h}$ (HAAM1).

D : Carbamoylethylated and carboxyethylated cellulose in $20 \%$ sodium hydroxide for $10 \mathrm{~h}$ (HAAM10).

Table 2. Change of radical concentration

\begin{tabular}{|c|c|c|c|c|}
\hline \multirow[t]{2}{*}{ Sample } & \multicolumn{4}{|c|}{ Relative radical concentration 1 ) } \\
\hline & dry & wet $^{2)}$ & dry-wet ${ }^{3)}$ & wet/dry 4$)$ \\
\hline$M$ & 100 & 29 & 71 & 0.29 \\
\hline HAAM1 & 109 & 12 & 97 & 0.11 \\
\hline HAAM 10 & 111 & 10 & 101 & 0.09 \\
\hline \multicolumn{5}{|c|}{$\begin{array}{l}\text { 1): Relative radical concentration to that of mercer- } \\
\text { ized cellulose under dry conditions. } \\
\text { 2): Dry sample was immersed in water at room } \\
\text { temperature for } 60 \text { min. } \\
\text { 3): Difference in the relative radical concentration } \\
\text { between the dry and wet samples. } \\
\text { 4): Ratio of the relative radical concentration of the }\end{array}$} \\
\hline
\end{tabular}

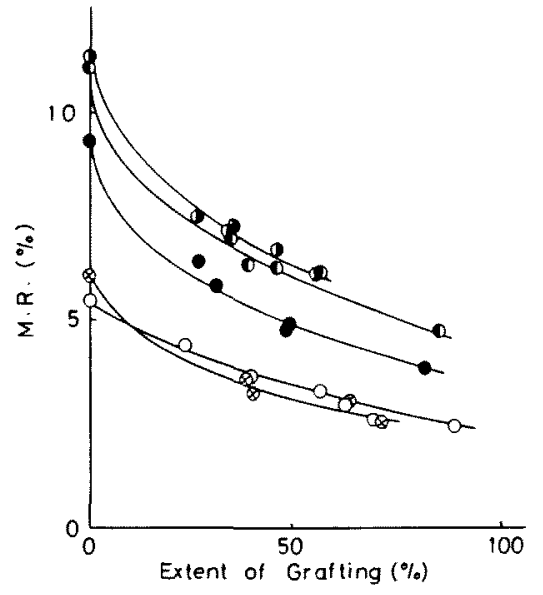

Fig. 2. Relation between extent of grafting and moisture regain (M.R.). Symbols are the same in Fig. 1. 


\section{Moisture Regain}

Moisture regain (M.R.) of the samples is plotted against extent of grafting in Figure 2. M.R. decreased as extent of grafting increased. The M.R. value was higher in HAAM10 sample than those for the other samples.

M.R. of the samples is expressed by

$$
\text { M.R. }(\%)=\frac{W_{\mathrm{wc}}+W_{\mathrm{wg}}+W_{\mathrm{wu}}}{W_{\mathrm{c}}+W_{\mathrm{g}}} \times 100
$$

where $W_{\mathrm{c}}$ and $W_{\mathrm{g}}$ are weights of cellulose and grafted polystyrene, respectively, and $W_{\mathrm{wc}}, W_{\mathrm{wg}}$ and $W_{\text {wu }}$ weights of water absorbed by cellulose, grafted polystyrene and unknown factors incidental to grafting reaction, respectively. Extent of grafting (G-on) can be expressed by equation (2).

$$
\text { G-on }(\%)=\frac{W_{\mathrm{g}}}{W_{\mathrm{c}}} \times 100
$$

From equations (1) and (2), M.R. can be written as

$$
\text { M.R. }(\%)=\left(\frac{W_{\mathrm{wc}}}{W_{\mathrm{c}}}+\frac{W_{\mathrm{wg}}}{W_{\mathrm{c}}}+\frac{W_{\mathrm{wu}}}{W_{\mathrm{c}}}\right) \times \frac{10^{4}}{100+\mathrm{G}-\mathrm{on}}
$$

where $W_{\mathrm{wc}} / W_{\mathrm{c}}$ is moisture regain by control sample (ungrafted sample) and is constant, $W_{\mathrm{wg}} / W_{\mathrm{c}}$ is nearly 0 because polystyrene does not absorb water practically. ${ }^{12)}$ If nothing occurs incidental to grafting reaction (namely $W_{\text {wu }} / W_{c}=0$ ), the

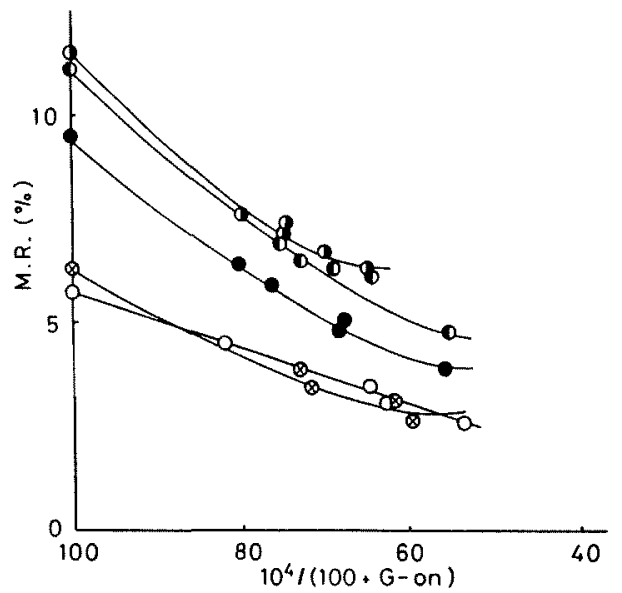

Fig. 3. Relation between $10^{4} /(100+$ G-on $)$ and moisture regain. Symbols are the same in Fig. 1. plot of M.R. against $10^{4} /(100+$ G-on) should be a straight line. The plot is shown in Figure 3. Sample U showed a straight line, but other samples showed slightly concave lines. So it is considered that some changes which are different from those observed in $U$ occur in the samples LAAM24, M, HAAM1 and HAAM10. According to R. Jeffries ${ }^{13)}$ and $L$. Valantine ${ }^{14)}$ practically the whole of the absorbed moisture is held in disordered regions of cellulose. So it is considered that M.R. reflects the structure of the amorphous regions of the samples. Considering the results, it can be said that amorphous regions in samples LAAM24, M, HAAM1 and HAAM10 are more affected than those in sample $U$. The tendency is more remarkable when grafting percent is lower in those samples.

In order to clarify the changes incidental to grafting reaction, M.R. was plotted against extent of grafting ignoring weight of grafted polystyrene; assuming that moisture is held only by cellulose part in grafted sample because polystyrene does not absorb water practically (M.R. $100\left(W_{w c}\right.$ $\left.\left.+W_{w u}\right) / W_{\mathrm{c}}\right)$. The plot is shown in Figure 4. M.R. of untreated cellulose decreased in a straight line with extent of grafting, but that of other samples decreased with two stages; the first stage is a rapid decrease of M.R. with extent of grafting and the second stage is a gradual decrease with the same slope as that for the untreated cellulose. Therefore

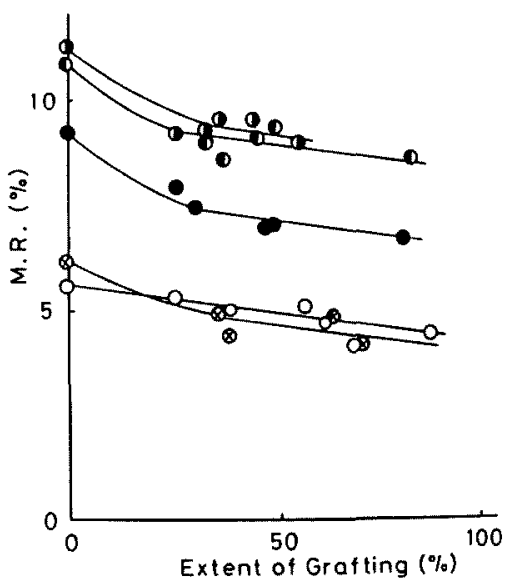

Fig. 4. Relation between extent of grafting and moisture regain ignoring weight of grafted polystyrene. Symbols are the same in Fig. 1. 
the first slope of samples but untreated cellulose means that grafted polystyrene is first introduced to highly hydrophilic part of the samples. The latter slope is considered to be related with the reduction of hydrophilic sites of celluloses incidental to introduction of grafted polystyrene to the amorphous regions of cellulose. And the second slope is independent of the samples.

\section{Water Imbibition}

Water imbibition (W.I.) of the samples is plotted against extent of grafting in Figure 5. In general, water can penetrate into the amorphous and semicrystalline regions of cellulose samples. Therefore, W.I. of the samples can reflect the structure of the amorphous and semicrystalline regions. Though all the samples gave curvatures in Fig. 5, the change in W.I. with extent of grafting for HAAM1 and HAAM10 is quite different from those for U, LAAM24 and M. These results may mean that regions to which grafted polystyrene was introduced and/or the effect of polystyrene on W.I. are different among the samples.

In the same way as for M.R., W.I. of the samples is plotted against $10^{4} /(100+\mathrm{G}$-on $)$ in Figure 6. As all the samples gave curvatures, it can be said that structural changes incidental to grafted polystyrene occurred therein. But the changes depend on the samples and extent of grafting because the change in W.I. with $10^{4} /(100$

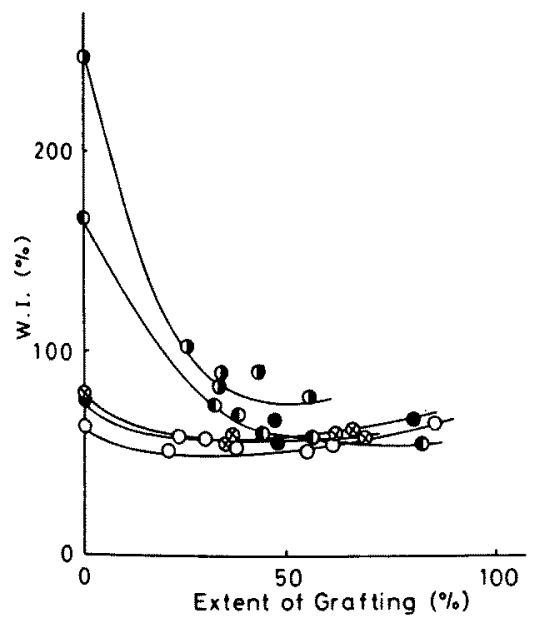

Fig. 5. Relation between extent of grafting and water imbibition (W.I.). Symbols are the same in Fig. 1.
+ G-on) are different among the samples. The change is remarkable for HAAM1 and HAAM10 at low extents of grafting.

As polystyrene does not absorb water, W.I. of the samples can be drawn ignoring weight of polystyrene as already done in moisture regain and is shown in Figure 7. W.I. of samples U, LAAM24 and M increased with extent of grafting, while that of samples HAAM1 and HAAM10 decreased rapidly and then increased gradually.

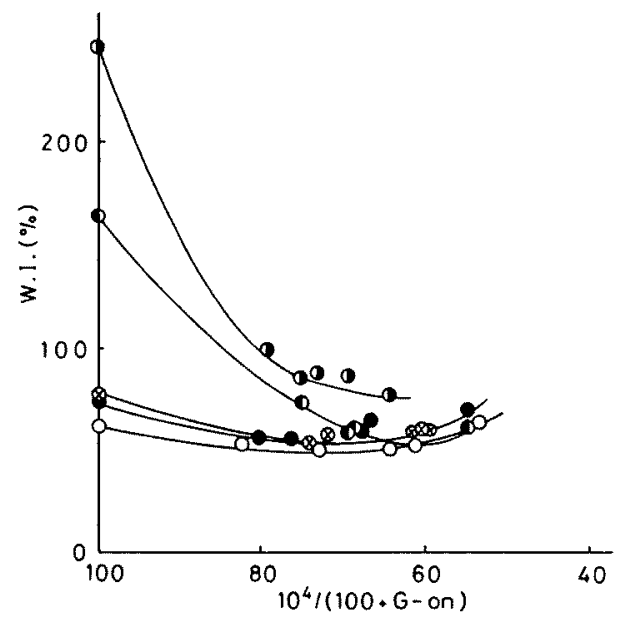

Fig. 6. Relation between $10^{4} /(100+\mathrm{G}$-on $)$ and water imbibition. Symbols are the same in Fig. 1.

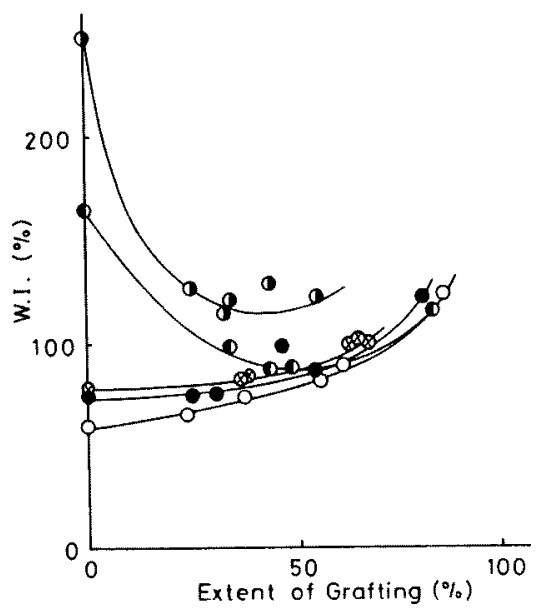

Fig. 7. Relation between extent of grafting and water imbibition ignoring weight of grafted polystyrene. Symbols are the same in Fig. 1. 
The increase of W.I. with extent of grafting means the increase in amount of hydrophilic site in the amorphous and semicrystalline regions in the samples. On the other hand, the rapid decrease of W.I. means the decrease in amount of hydrophilic sites in celluloses with introduction of polystyrene grafts. A further discussion will be given later.

Degree of Crystallinity Estimated by X-ray

\section{Diffraction Method}

The degree of crystallinity (D.C.) measured under dry and wet conditions before and after the grafting reaction is shown in Table 3. As corrections mentioned in experimental part were all done, D.C. values are those of the cellulose part of the grafted samples.

Comparing D.C. of control samples, it is clear that $U$ and LAAM24 have higher values than $M$, HAAM 1 and HAAM 10 under both dry and wet conditions. Ratio of D.C., wet/dry shows a measure of rigidity of the crystalline regions. Therefore, U, LAAM24 and M are thought to have rigid crystalline regions and few semicrystalline regions, the latter appearing as crystalline regions in dry state and as amorphous regions in wet state in water. On the other hand, samples HAAM1 and HAAM10 may have somewhat disordered crystal structure and many semicrystalline regions and decrease in D.C. under the wet conditions.

For all grafted samples, degree of crystallinity (D.C.) measured under dry conditions changed a little as compared with that for control samples. But under the wet conditions, D.C. decreased as extent of grafting increased in U, LAAM24 and $M$ samples, and increased in HAAM1 and HAAM10 samples. Although ratio of D.C., wet/dry shows a measure of the extent to which water can penetrate into the apparent crystalline regions even after grafting reaction, the degree of water penetration was different among the samples. Ratio of D.C. graft/control shows a change of D.C. by grafting reaction. As the values ranged from 0.89 to 1.19 when measured under dry conditions, there are only little change in D.C. by grafting reaction in appearance in all samples. But under the wet conditions, the values decreased as extent of grafting increased for U, LAAM24 and M samples, but increased for HAAM1 and HAAM10 samples. This result means that grafted polystyrene branch deteriorates the crystalline regions of samples $\mathrm{U}$, LAAM24 and M, but not in case of HAAM1 and HAAM10 samples. In fact, water can not penetrate into the semicrystalline regions of the grafted

Table 3. Degree of crystallinity measured under dry and wet conditions

\begin{tabular}{|c|c|c|c|c|c|c|}
\hline \multirow[t]{3}{*}{ Sample } & \multirow{3}{*}{$\begin{array}{c}\text { Extent of } \\
\text { grafting } \\
(\%)\end{array}$} & \multirow{2}{*}{\multicolumn{2}{|c|}{$\begin{array}{l}\text { Degree of } 1) \\
\text { crystallinity }\end{array}$}} & \multicolumn{3}{|c|}{ Ratio of D.C. $\left.{ }^{2}\right)$} \\
\hline & & & & wet/dry & Graft/ & ontrol \\
\hline & & dry (\%) & wet $(\%)$ & & & \\
\hline \multicolumn{7}{|l|}{$\mathrm{U}$} \\
\hline Control & 0 & 46.1 & 42.1 & 0.91 & - & - \\
\hline Graft & 31.6 & 44.6 & 45.3 & 1.02 & 0.97 & 1.07 \\
\hline Graft & 62.1 & 40.8 & 19.3 & 0.47 & 0.89 & 0.49 \\
\hline \multicolumn{7}{|l|}{ LAAM 24} \\
\hline Control & 0 & 48.7 & 41.7 & 0.86 & - & - \\
\hline Graft & 37.7 & 47.5 & 34.3 & 0.72 & 0.98 & 0.82 \\
\hline \multicolumn{7}{|l|}{$M$} \\
\hline Control & 0 & 33.6 & 31.5 & 0.94 & - & - \\
\hline Graft & 30.3 & 36.3 & 34.1 & 0.94 & 1.08 & 1.08 \\
\hline Graft & 49.2 & 38.2 & 27.9 & 0.73 & 1.14 & 0.89 \\
\hline \multicolumn{7}{|l|}{ HAAM1 } \\
\hline Control & 0 & 34.1 & 22.4 & 0.70 & - & - \\
\hline Graft & 35.8 & 31.8 & 27.6 & 0.87 & 0.93 & 1.23 \\
\hline Graft & 58.2 & 36.5 & 34.7 & 0.95 & 1.07 & 1.55 \\
\hline \multicolumn{7}{|l|}{ HAAM 10} \\
\hline Control & 0 & 28.3 & 14.4 & 0.51 & - & - \\
\hline Graft & 30.5 & 33.8 & 30.0 & 0.89 & 1.19 & 2.08 \\
\hline
\end{tabular}

1) Degree of crystallinity of cellulose part in sample

2) D.C. denotes degree of crystallinity 
samples so easily as in the case of control samples. These results are consistent with the results of W.I. To say, samples U, LAAM24 and M do not lose their hydrophilic nature by grafting reaction, but samples HAAM1 and HAAM10 do. These results arise from the difference in structure of trunk polymers; the regions where polystyrene branches are introduced by grafting reaction are different from the trunk polymers and extent of grafting. The results of water imbibition imply that the crystalline regions of highly grafted HAAM1 and HAAM10 may be destroyed by grafting of polystyrene. It is, therefore, considered that polystyrene grafts are introduced into highly hydrophilic regions at first, then to the amorphous and semicrystalline regions, and finally to the crystalline regions, disarranging the crystal regions in all the samples. As the size of each region is different among the samples, different phenomena were observed in M.R., W.I. and D.C.

\section{CONCLUSION}

From the results mentioned above, it can be said that polystyrene grafts are introduced to amorphous regions of cellulose in the first stage of grafting reaction and then to semicrystalline and crystalline regions with disarranging the crystal structure in all samples. The same phenomena are found in all samples, but the degree of grafting beyond which disarranging of the crystalline regions occurs depends on the samples. In other words, amounts of the amorphous and semicrystalline regions determine the behavior of grafting reaction.
Acknowledgment The $r$-ray irradiation work associated with this study was conducted in the irradiation facility of the Japan Atomic Energy Research Institute at Takasaki.

\section{References}

1) J.W. Frick, W. A. Reeves and J. D. Guthrie, Text. Res. J., 27, 92 (1957)

2) J. W. Frick, W. A. Reeves and J. D. Guthrie, Text. Res. J., 27, 294 (1957)

3) R. M. Reinhadt and J. S. Bruno, J. Appl. Polym. Sci., 10, 387 (1966)

4) M. Shimada, H. Kuribara, I. Matsumoto and Y. Nakamura, J. Appl. Polym. Sci., 24, 1017 (1979)

5) I. Sakurada, T. Okada and E. Kugo, Doitai To Hoshasen, 2, 297 (1959)

6) S. Dilli and D. L. Garnett, J. Polym. Sci., A-1, 2323 (1966)

7) S. Dilli and D. L. Garnett, Aust. J. Chem., 24, 981 (1971)

8) G. Ordian, M. Sobel, A. Rossi and R. Klein, J. Polym. Sci., 55, 663 (1961)

9) R. Y.M. Huang and W. H. Rapson, J. Polym. Sci., Pt. C(2), 169 (1963)

10) C. Simionescu and S. Oprea, Cellulose Chem. Technol., 4, 471 (1970)

11) Y. Nakamura and M. Shimada, ACS Symposium Ser., 48, 298 (1977)

12) V. A. Matonis, "Polymer Handbook", Second Ed., John Wiley \& Sons, New York, p VIII-6 (1974)

13) R. Jeffries, J. Appl. Polymer Sci., 8, 1213 (1964)

14) L. Valantine, J. Polymer Sci., 27, 313 (1958)

\section{スチレングラフトセルロースの微細構造}

\section{群馬大学工学部島田真知子，川上佳彦，赤堀博一，中村好婎}

親水性の異なる各種セルロース試料，すなわち末処理 綿セルロース，マーセル化セルロース，3\%あるいは20 水酸化ナトリウム中アクリルアミドでカルパモイルエ チル化およびカルボキシルエチル化したセルロースに 線を照射し，スチレンのグラフト重合反応を行った。得 られたスチレングラフトセルロースの微細櫵造を，吸湿 率, 吸水率ならびに結晶化度测定により追究した。その 結果, グラフトスチレンは全ての試料で, 非晶領域から
擬結晶領域，更にグラフト率が高くなると結晶領域を一 部破買しなから結晶領域へと加着していくことが明らか にされた。しかしながら，非晶領域ならしに結晶領域の 量が試料によって異なるために，吸湿率・吸水率のグラ フト率依存性か，見加け上試料により異なるものと推定 された。すなわち，韭晶領域ならびに擬結晶領域量がグ

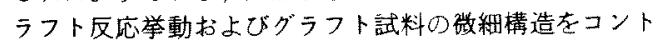
ロールするすのと考えられる。 